\title{
ENTREPRENEURSHIP EDUCATION IN PESANTREN: STRATEGIES TO DRIVE STUDENTS' INTEREST IN ENTREPRENEURSHIP
}

\author{
Idi Warsah \\ State Institute of Islamic Studies (IAIN) Curup \\ Email: idiwarsah@iaincurup.ac.id
}

\begin{abstract}
Today, educational competitiveness is getting tougher. Viewing this condition, Pesantren strives to explore students' potential in entrepreneurship because the educational world must capably play an active role in preparing educated and readyto-work human resources. This study sought to find a depiction of entrepreneurship education in Pesantren Darussalam of Kepahiang by applying a descriptive qualitative approach. This study revealed that first, students were fully directed and guided through courses based on their talents and interests, and they were taught to get working experiences directly. Second, the supporting factors encompassed full supports and appreciation from Pesantren Darussalam, available facilities for entrepreneurship, and full societal supports. Subsequently, the inhibiting factors included inadequate external organizations that could broadly cover students to participate in entrepreneurial activities in a more prolonged way, and some students still had less enthusiasm to benefit from Kiai and teachers' support.
\end{abstract}

Abstrak: Saat ini persaingan dalam dunia pendidikan semakin ketat. Mencermati kondisi tersebut, pihak Pondok Pesantren berusaha menggali potensi para santri di bidang kewirausahaan, karena dunia pendidikan harus mampu berperan aktif menyiapkan sumber daya manusia terdidik dan siap kerja. Menyikapi hal tersebut, dengan menggunakan metode deskriptif kualitatif, penelitian ini berusaha menemukan gambaran tentang pendidikan kewirausahaan di Pesantren Darussalam yang terletak di Kabupaten Kepahiang, Provinsi Bengkulu, Indonesia. Penelitian ini mengungkapkan bahwa: Pertama, para santri diarahkan dan dibimbing dengan penuh tanggung jawab melalui penyediaan tempat kursus sesuai dengan bakat dan minatnya serta mereka diajarkan untuk terlibat dalam praktik kerja secara langsung. Kedua, factor pendukungnya yaitu: dukungan dan apresiasi penuh dari Pembina Pondok Pesantren Darussalam; tersedianya beberapa fasilitas-fasilitas pendukung yang berhubungan dengan kewirausahaan; dan dukungan penuh dari masyarakat sekitar. Faktor penghambatnya yaitu: keberadaan organisasi dari pihak luar yang mewadahi santri dalam melaksanakan kegiatan kewirausahaan belum mencukupi dan sebagian santri masih belum memiliki 
antusias tinggi untuk memanfaatkan dukungan yang sudah diberikan oleh Kiai dan para ustadz and ustadzah.

Keywords: entrepreneurship; education; santri (Islamic students)

\section{INTRODUCTION}

Islamic boarding schools (hereafter as Pesantrens) were established by Muslim scholars independently as part of responsibility and obedience to Allah SWT in teaching, practicing, and preaching His Religion's doctrine ${ }^{1}$. Besides, Pesantrens also contain some different curriculums. However, to some extent, there is a similar function of Pesantren education to general education. Other than being oriented towards Islamic education, Pesantrens also teach other sciences and knowledge in general ${ }^{2}$.

Pesantren has important functions as a forum and at the same time as a center for the regeneration of religious thinkers ${ }^{3}$. Pesantren plays a role as an institution that seeks to produce superior human resources and benefit the community ${ }^{4}$. For this reason, this institution is understood as a forum that participates in making societal changes ${ }^{5}$.

To some extent, today's competitive era means that competition in education is very difficult. As demonstrated in the phenomenon found at Pesantren Darussalam in Kepahiang Regency, Bengkulu as the field of this study, the graduates or alumni who will continue to a higher level of education through processes of both tests, national selection for the state higher education (SNMPTN), joint selection of state university entrance (SBMPTN), and the achievement scholarship program for santri (PBSB), on average, they have not

1 Imam Syafe'i, "Pondok Pesantren: Lembaga Pendidikan Pembentukan Karakter," AlTadzkiyyah: Jurnal Pendidikan Islam 8, no. 1 (2017): 61-82; Heri Cahyo Bagus Setiawan, "Kontribusi Praktik Kewirausahaan Di Pondok Pesantren (Studi Pada Pondok Pesantren Entrepreneur Mukmin Mandiri, Waru Sidoarjo)," Jurnal Riset Entrepreneurship 2, no. 2 (2019): 8-18; H. M. Djumransjah, "Pendidikan Pesantren Dan Kemandirian Santri," Jurnal Ilmu Pendidikan 8, no. 2 (2016).

2 Rz Ricky Satria Wiranata, "Tantangan, Prospek Dan Peran Pesantren Dalam Pendidikan Karakter Di Era Revolusi Industri 4.0,” Journal Al-Manar 8, no. 1 (2019): 61-92.

3 Mukaffan and Ali Hasan Siswanto, 'Modernisasi Pesantren Dalam Konstruksi Nurcholish Madjid', Cendekia, 17.2 (2019), 285-300; Ahmad Natsir, 'Identitas Poskolonialisme Pesantren Modern', Cendekia, 17.2 (2019), 203-18.

4 Muhammad Khoiruddin, 'Integrasi Kurikulum Pesantren Dan Perguruan Tinggi', Cendekia, 17.2 (2019), 219-34.

${ }^{5}$ Anshori Maulana Ahmad and Yefni Yefni, "Kontribusi Pondok Pesantren Hafizh AlQur'an Al-Fath dalam Pembangunan Masyarakat di Kampung Benteng Hulu Kecamatan Mempura Kabupaten Siak," Jurnal Riset Mahasiswa Dakwah Dan Komunikasi 2, no. 1 (2020): $31-36$. 
succeeded in various universities they are aiming. Due to their low academic field ability, and even cannot continue to the next level caused by several factors, such as economic problems. Viewing these conditions, Pesantren Darussalam of Kepahiang Regency initiates opportunities for students to explore their potential in entrepreneurship because education must play an active role in preparing educated human resources ${ }^{6}$.

The above problem reinforces the general assumption that Pesantrens are still seen as educational institutions that will only produce prospective Kiai or the so-called religious experts who do not have expertise in other fields. However, this has certainly been disproved by the results of Saeful Anam's research that business capabilities contained in Pesantren's curriculum become a new paradigm for the progress of Islamic religious education through the merging of tafaqquh fî al-dîn and tafaqquh fì al-tijârah .

Imam Syafe'i, in his research, emphasized that Pesantren is a partner for governmental institutions to improve the quality of education as a forum that focuses on increasing superior human resources in all fields and at the same time it still prioritizes morality ${ }^{8}$. Thus, Pesantren's alumni are expected to compete in the business world according to their competencies during their studying time as santri (Islamic students) at the institution.

As a concrete example, the Al-Ittifaq Pesantren in Bandung has proven its role in developing students to build an entrepreneurial enthusiasm in accordance with the potential of natural resources within the Pesantren's environment ${ }^{9}$. Likewise, Pesantren Darussalam Gontor Putri 1 seeks to develop students' entrepreneurial enthusiasm in a way that produces students who are creative and innovative ${ }^{10}$. In such a way, Pesantren produces students that can compete in the world of work, and at the same time, Pesantren shares with students the knowledge about how to develop a business by providing training services on how entrepreneurs seize opportunities and find solutions to challenges that will be faced in the future ${ }^{11}$.

${ }^{6}$ Interview with a teacher in Pesantren Darussalam, October 2nd, 2019

7 Saeful Anam, "Pesantren Entrepreneur Dan Analisis Kurikulum Pesantren Mukmin Mandiri Waru Sidoarjo Dalam Pengembangan Dunia Usaha,” Maraji: Jurnal Ilmu Keislaman 2, no. 2 (2016): 304-329.

8 Syafe'i, "Pondok Pesantren."

9 Yusni Fauzi, "Peran Pesantren Dalam Upaya Pengembangan Manajemen Sumber Daya Manusia (Msdm) Entrepreneurship (Penelitian Kualitatif Di Pondok Pesantren Al-Ittifaq Rancabali Bandung)," Jurnal Pendidikan UNIGA 6, no. 1 (2017): 1-8.

${ }^{10}$ Zuanita Andriyani, M. Azmi Hasan, and Retno Ayu Wulandari, "Membangun Jiwa Enterpreneurship Santri Melalui Pengembangan Usaha Ekonomi Kreatif," Dimas: Jurnal Pemikiran Agama Untuk Pemberdayaan 18, no. 1 (2018): 47-64.

${ }^{11}$ Ririn Noviyanti, "Peran Ekonomi KreatifTerhadap Pengembangan Jiwa Entrepreneurship Di Lingkungan Pesantren,” INTAJ: Jurnal Penelitian Ilmiah 1, no. 1 (2017): 77-99. 
Entrepreneurship is an activity to improve people's welfare in the sense of a better quality of life, attitude, and actions or ability to make something unique and useful for others and oneself ${ }^{12}$. Hamdani in Mubarok explained that entrepreneurship is known as a person's ability to do and produce new things that benefit both him and others ${ }^{13}$. The term entrepreneur is derived from the French language. In English, it is commonly known by the term between taker or goes between, which means people who dare to act to take opportunities ${ }^{14}$.

Furthermore, a study explains that entrepreneurship is an interdisciplinary field of study. More importantly, entrepreneurship is thoroughly related to business education ${ }^{15}$. In the context of entrepreneurship education in Pesantren, Siswato's study indicated that Kiai (Islamic grand teachers or experts), santri (Islamic students), and the alumni of Pesantren play an important role in the development of entrepreneurship at Pesantren, especially entrepreneurship affiliated with transparency, professionalism, honesty, and trustworthiness ${ }^{16}$. The foregoing study confirms that Pesantren's formation must play an active role in empowering students to become entrepreneurs by utilizing existing facilities, both through guidance and direction from Kiai, responsible for this by providing good and maximum guidance. The way as such indicates an ideal effort to develop students' entrepreneurial potential as the effort made at Pesantren Darussalam of Kepahiang.

Responding to the phenomenon above, this study seeks to answer the following research questions: what are the efforts made by Kiai, teachers, and students in entrepreneurship education at Pesantren Darussalam of Kepahiang? What are the supporting and inhibiting factors faced by the members of Pesantren in implementing entrepreneurship education?

\section{RESEARCH METHOD}

This study applied a qualitative approach because qualitative research could describe, analyze, and map activities, processes, and meanings existing in the

${ }^{12}$ Rekno Sulandjari, "Strategi Komunikasi Pemasaran Pada Minat Berwirausaha Produk Lokal (Kerajinan Bambu) Di KWD Kelurahan Pulutan Kecamatan Sidorejo Kota Salatiga," Jurnal Egaliter 2, no. 03 (2018).

${ }^{13}$ Achmat Mubarok, "Pendidikan Entrepreneurship dalam Meningkatkan Kemandirian Santri Pondok Pesantren Al-Hidayah Ii Sukorejo Pasuruan,” Al MurabbI 4, no. 1 (2018): 1-22.

${ }^{14}$ Iin Nurbudiyani, "Model Pembelajaran Kewirausahaan Dengan Media Koperasi Sekolah Di SMK Kelompok Bisnis Dan Manajemen,” Jurnal Pendidikan Vokasi 3, no. 1 (2013).

${ }^{15}$ Gerald E. Hills and Michael H. Morris, "Entrepreneurship Education: A Conceptual Model and Review," in Educating Entrepreneurs for Wealth Creation (Routledge, 2018), 38-53.

${ }^{16}$ Siswanto Siswanto, "The Exploration of Pesantren-Based Entrepreneurship Development Strategy Through IEology Approach,”El Harakah 20, no. 2 (2018): 191. 
phenomena relevant to the studied problems in detail ${ }^{17}$. According to Bodgan and Taylor in Hadi, Sukajat, and Anggito, a qualitative study is a research that intends to understand a phenomenon concerning what is experienced by the studied subjects such as behavior, perception, motivation, and action in holistic ways utilizing descriptions in the form of words and language ${ }^{18}$. This study is field research because the researcher jumps directly into the field to obtain data that can be trusted from a predetermined research field ${ }^{19}$.

In this study, the subjects were selected using the purposive sampling technique by relying on certain considerations assigned based upon the study context. Considering the research objectives to be achieved, the researcher decided that the subjects to be studied were the teachers who were responsible in the field of entrepreneurship and all students of class XII at Pesantren Darussalam of Kepahiang. Those students were selected because entrepreneurial activities were held at the level of class XII. The data were obtained from interviews with teachers and some students and strengthened by the data garnered from observation and documentation ${ }^{20}$. In the present study, data analysis techniques used interactive data analysis, as recommended by Miles, Huberman, and Saldana. This data analysis aimed to provide an overview of the research subjects based on the data obtained from the subjects studied so that the conclusions drawn were accurate and academically responsible ${ }^{21}$.

${ }^{17}$ Purificación Gironés Guillem et al., "Qualitative Research Process Applied to Organ Donation,” 2018; Nanang Martono, Metode Penelitian Kuantitatif: Analisis Isi Dan Analisis Data Sekunder (Sampel Halaman Gratis) (RajaGrafindo Persada, 2010); I. Wayan Suwendra, Metodologi Penelitian Kualitatif Dalam Ilmu Sosial, Pendidikan, Kebudayaan Dan Keagamaan (Nilacakra, 2018).

${ }^{18}$ Sumasno Hadi, "Pemeriksaan Keabsahan Data Penelitian Kualitatif Pada Skripsi," Jurnal Ilmu Pendidikan 22, no. 1 (2017); Ajat Rukajat, Pendekatan Penelitian Kualitatif (Qualitative Research Approach) (Deepublish, 2018); Albi Anggito Setiawan Johan, Metodologi penelitian kualitatif (CV Jejak (Jejak Publisher), 2018).

${ }^{19}$ Karen Jiggins Colorafi and Bronwynne Evans, "Qualitative Descriptive Methods in Health Science Research,” HERD: Health Environments Research \& Design Journal 9, no. 4 (2016): 16-25; Lexi J. Moleong, Methodology of Qualitative Research (Bandung: Remaja Rosda Karya, 2010); Dedi Supriadi, "Pokoknya Kualitatif: Dasar-Dasar Merancang Dan Melakukan Penelitian Kualitatif,” Jakarta: PT. Dunia Pustaka Jaya, 2011.

${ }^{20}$ Kathryn Roulston, "Analysing Interviews," The Sage Handbook of Qualitative Data Analysis, 2014, 297-312.

${ }^{21}$ Matthew B. Miles, M. A. Huberman, and Johnny Saldana, "Drawing and Verifying Conclusions. Qualitative Data Analysis: A Methods Sourcebook," 2014; Matthew B. Miles, A. Michael Huberman, and Johnny Saldaña, Qualitative Data Analysis: A Methods Sourcebook. 3rd (Thousand Oaks, CA: Sage, 2014). 


\section{LITERATURE REVIEW}

\section{Pesantren}

The etymology of Pesantren derives from the basic word santri, whereas santriperse derives from the Sanskrit language known as Shastri, which means a group of people who have knowledge as regards Hindu religious sources or religious experts who have extensive knowledge of the Hindu holy books ${ }^{22}$. Therefore, if viewed from the foregoing definition, Pesantren refers to an institution rooted in two different cultures, but in some way, it originates from the history of religious education institution development in the archipelago ${ }^{23}$. In other words, this educational institution is one model of Islamic education that has long existed in the archipelago.

Imam Syafe' $i$, in his research, emphasized that Pesantren is a partner for governmental institutions to improve the quality of education as a forum that focuses on increasing superior human resources in all fields and at the same time it still prioritizes morality ${ }^{24}$. Thus, the alumni of Pesantren are expected to compete in the business world according to their competencies during their studying time as santri (Islamic students) at the institution.

To prepare superior generations in the future, of course, the management of institutions must make appropriate and measurable breakthroughs ${ }^{25}$, including reviewing the curriculum that has been oriented towards fulfilling religious competence alone ${ }^{26}$. By doing so, Pesantren can become a reference and center for education and knowledge in Indonesia. In this case, the researcher refers to the results of Asmani's research, which has concluded that Pesantren will be a reference for knowledge if Pesantren can answer the challenges of today's era by equipping students not only with religious knowledge but also with worldly knowledge such as how they can be entrepreneurs ${ }^{27}$.

\section{Entrepreneurship and Entrepreneurship Education}

Entrepreneurship is a process of creating something new that is valuable by devoting time and effort and taking risks to achieve success. Likewise, entrepreneurship is associated with creativity, optimism, and courage and can

${ }^{22}$ Agus Miftakus Surur, "Peningkatan Kemampuan Khatabah (Public Speaking Skill) Santri Ma'had Darul Hikmah Iain Kediri,” Ijaz Arabi Journal of Arabic Learning 1, no. 2 (2018)

${ }^{23}$ Nur Kholis, "Pondok Pesantren Salaf Sebagai Model Pendidikan Deradikalisasi Terorisme,” Akademika: Jurnal Pemikiran Islam 22, no. 1 (2017): 153-172.

${ }^{24}$ Syafe'i, "Pondok Pesantren."

${ }^{25}$ Idi Warsah and Muhamad Uyun, 'Kepribadian Pendidik: Telaah Psikologi Islami', Psikis : Jurnal Psikologi Islami, 5.1 (2019), 62-73 <https://doi.org/10.19109/psikis.v5i1.3157>.

${ }^{26}$ Idi Warsah, 'Pendidikan Keimanan Sebagai Basis Kecerdasan Sosial Peserta Didik: Telaah Psikologi Islami', Psikis: Jurnal Psikologi Islami, 4.1 (2018), 1-16.

${ }^{27}$ Jamal Ma'mur Asmani, "Pesantren Sebagai 'Kiblat' Pendidikan dan Pengetahuan Indonesia,” Islamic Review: Jurnal Riset Dan Kajian Keislaman 5, no. 1 (2016): 59-84. 
identify opportunities ${ }^{28}$. Thus, entrepreneurship corresponds to a person who develops every potential and ability he has ${ }^{29}$. To some extent, entrepreneurship relates to people who do their own business or activities with all their capabilities. In the meantime, entrepreneurship also shows the mental attitude in carrying out a business or activity ${ }^{30}$.

In education, entrepreneurship education can certainly be realized when held strategically as it aims at economic development and job creation ${ }^{31}$. Furthermore, a study explains that entrepreneurship is an interdisciplinary field of study. More importantly, entrepreneurship is thoroughly related to business education $^{32}$. In the context of entrepreneurship education in Pesantren, Siswato's study indicated that Kiai (Islamic grand teachers or experts), santri (Islamic students), and the alumni of Pesantren play an important role in the development of entrepreneurship at Pesantren, especially entrepreneurship affiliated with transparency, professionalism, honesty, and trustworthiness ${ }^{33}$. The foregoing study confirms that Pesantren's formation must play an active role in empowering students to become entrepreneurs by utilizing existing facilities, both through guidance and direction from Kiai, responsible for this by providing good and maximum guidance. The way as such indicates an ideal effort to develop students' entrepreneurial potential as the effort made at Pesantren Darussalam in Kepahiang Regency of Bengkulu Province.

${ }^{28}$ Sukanti Sukanti, Aliyah Rasyid Baswedan, and Isroah Isroah, "Peran Ibu Dalam Menumbuhkan Jiwa Wirausaha Anak,” Jurnal Pendidikan Akuntansi Indonesia 9, no. 2 (2011).

${ }^{29}$ Umi Rochayati, Mahardhika Setia Kusumawardani, and Arum Kartika Sari, "Pengaruh Faktor Sosiodemografi, Sikap, dan Kontekstual terhadap Niat Berwirausaha Siswa," Jurnal Kependidikan: Penelitian Inovasi Pembelajaran 43, no. 2 (November 1, 2013), https://doi. org/10.21831/jk.v43i2.1970.

30 Titi Rahayu, "Menumbuhkan Jiwa dan Kompetensi Kewirausahaan Berbasis Syariah Bagi Mahasiswa Fakultas Ekonomi Dan Bisnis Islam Institut Agama Islam Bakti Negara (Ibn) Tegal,” Iqtishodiah: Jurnal Ekonomi Dan Perbankan Syariah 1, no. 1 (2019): 73-88; Gertruida Johona Rumawouw, "Praktek Wirausaha Bagi Mahasiswa dalam Meningkatkan Ekonomi," Prosiding Aptekindo 6, no. 1 (2012); Ari Riswanto, "Pendampingan Kreativitas Dan Kemandirian: Pendidikan Calon Wirausahawan Muda," Edusentris 3, no. 3 (2016): 300-305.

${ }^{31}$ W. Ed Mcmullan and Wayne A. Long, "Entrepreneurship Education in the Nineties," Journal of Business Venturing 2, no. 3 (1987): 261-275.

${ }^{32}$ Gerald E. Hills and Michael H. Morris, "Entrepreneurship Education: A Conceptual Model and Review," in Educating Entrepreneurs for Wealth Creation (Routledge, 2018), 38-53.

33 Siswanto Siswanto, "The Exploration of Pesantren-Based Entrepreneurship Development Strategy Through DEology Approach,”El Harakah 20, no. 2 (2018): 191. 


\section{FINDINGS AND DISCUSSION}

\section{Teachers' Coaching Patterns in Developing Students' Entrepreneurship Potential}

The presence of coaching patterns set to shape and build better students' personality is of very importance. There are several forms of coaching patterns commonly applied at Pesantren, namely authoritarian, democratic, and permissive coaching ${ }^{34}$. Practically, these three patterns are often applied in fostering students at Pesantren. In principle, concerning an authoritarian coaching pattern, parents or coaches have full authority to regulate their children or students, and the children or students must obey ${ }^{35}$. A permissive coaching pattern emphasizes the habits of children ${ }^{36}$. Coaching in this pattern is not as strong as the authoritative(democratic) coaching pattern. An authoritative(democratic) coaching pattern demonstrates that fostering democracy is more inclined to the principle of harmony and balance between parents' and children's desires so that good communication occurs ${ }^{37}$. Authoritative coaching is considered more constructive for students' development ${ }^{38}$.

${ }^{34}$ Lindsey Susan Aloia and Ron Warren, 'Quality Parent-Child Relationships: The Role of Parenting Style and Online Relational Maintenance Behaviors', Communication Reports, 0.00 (2019), 1-14 <https://doi.org/10.1080/08934215.2019.1582682>

${ }^{35}$ Masayo Uji and others, 'The Impact of Authoritative, Authoritarian, and Permissive Parenting Styles on Children's Later Mental Health in Japan: Focusing on Parent and Child Gender', Journal of Child and Family Studies, 23.2 (2014), 293-302 <https://doi.org/10.1007/ s10826-013-9740-3>; Keith A. King, Rebecca A. Vidourek, and Ashley L. Merianos, 'Authoritarian Parenting and Youth Depression: Results from a National Study', Journal of Prevention and Intervention in the Community, 44.2 (2016), 130-39 <https://doi.org/10.1080/10852352.20 16.1132870>; Stelios N. Georgiou, Panayiotis Stavrinides, and Kyriaki Fousiani, 'Authoritarian Parenting, Power Distance, and Bullying Propensity', International Journal of School and Educational Psychology, 1.3 (2013), 199-206 <https://doi.org/10.1080/21683603.2013.80623 4>

${ }^{36}$ Alison L. Barton and Jameson K. Hirsch, 'Permissive Parenting and Mental Health in College Students: Mediating Effects of Academic Entitlement', Journal of American College Health, 64.1 (2016), 1-8 <https://doi.org/10.1080/07448481.2015.1060597>; Uji and others; Baumrind; Lee Shumow, Deborah Lowe VandellL, and Jill K. Posner, 'Harsh, Firm, and Permissive Parenting in Low-Income Families', Journal of Family Issues, 19.5 (1998), 483-507 <https://doi.org/10.1177/019251398019005001>

${ }^{37}$ Sumari Mawardi, "Pola Pendidikan Kyai Abdul Malik Luqoni Pengasuh Pondok Pesantren Minhajut Thullab Sumberberas Muncar Banyuwangi,” Jurnal Darussalam: Jurnal Pendidikan, Komunikasi Dan Pemikiran Hukum Islam 8, no. 1 (2016): 95-114.

${ }^{38}$ Eva Yi Hung Lau and Thomas G. Power, 'Coparenting, Parenting Stress, and Authoritative Parenting among Hong Kong Chinese Mothers and Fathers', Parenting, 2019, 1-10 <https:// doi.org/10.1080/15295192.2019.1694831>; Huiguang Ren and others, 'Maternal Attribution and Chinese Immigrant Children's Social Skills: The Mediating Role of Authoritative Parenting Practices', Parenting Science and Practice, 2019, 1-11 <https://doi.org/10.1080/15295192.20 19.1694834> 
Based on data from an interview with Ustadz Slamet Ridwan as the coach of OSPPMD, students' organization of Darussalam modern Pesantren (in Indonesian abbreviation known as OSPPMD) is a container that functions to coordinate students' activities in the extracurricular field. There are several extracurricular activities at Pesantren Darussalam. Seeing this, the teachers apply joint education patterns extending to authoritarian, democratic, and permissive education patterns that are applied in accordance with the problems encountered. It is noteworthy that the patterns of circumstances encountered vary, so automatically, the educational patterns applied should also vary. However, such patterns have the same goals and intentions ${ }^{39}$.

At Pesantren Darussalam of Kepahiang Regency in Bengkulu Province, students are also guided on how to deal with life after graduation. One of which is by participating in entrepreneurial activities to get their provisions independently. Entrepreneurship is one solution that can solve the problem of unemployment. One very prominent coaching pattern in this Pesantren concerning entrepreneurship is that students are taken to various business or work fields, including sewing courses (convection) and oyster mushroom cultivation.

In connection with this matter, the interview data with the main coach (Coordinator), in charge of students' entrepreneurship field, concerning how teachers guide and direct students in carrying out entrepreneurship activities at the Pesantren revealed: "When students are at class XII, extracurricular activities are not included any more because students will be more focused on the preparation of National Examination. In this condition, students' free time will be replaced by supporting activities, one of which is entrepreneurship activities. The method or strategy undertaken is primarily by giving students free time or as much time as possible to participate in the existing entrepreneurship activities. They are required to be creative to explore their potential with an educational pattern containing ways such as interaction, communication, guiding, and directing students to participate in entrepreneurship activities optimally"40.

The information above was confirmed by Ustadz Heru, who said: "Entrepreneurship is a program that we have agreed on, and it is good as well as very beneficial for students. Hence, as educators, we should convey knowledge in the classroom and think about developing students' potential. When our students are about to end their education, the most common thing we encounter is that they experience a little confusion between continuing college, working, and even not having any choice. In response to this, we provide the widest opportunity for

\footnotetext{
${ }^{39}$ Interview with Ustadz Slamet Ridwan, October 20th, 2019

${ }^{40}$ Interview with the coach coordinator of Darussalam's entrepreneur activities, October 23rd, 2019
} 
students to participate in entrepreneurship activities. In this case, of course, we implement an educational pattern that includes guidance and full responsibility from Ustadz and Ustadzah"41.

Related to the educational patterns adopted by Ustadz or Ustadzah in guiding students to participate in entrepreneurship activities, the researcher conducted interviews with the Assistant Counsel (members) taking charge of this activity. According to Ustadz Agus Salim, "to guide, direct, and foster students in terms of entrepreneurship activities, Ustadz and Ustadzah implement several educational patterns, including democratic and permissive educational patterns. A democratic pattern is used for those who still need guidance and direction or more attention. However, for those who are easily directed or regulated, a permissive pattern will be used to be independent without having to be accompanied by a coach. It is certainly not intended to distinguish between one another, but all have respective purposes and objectives. However, it should be understood that from some of the educational patterns applied, the democratic pattern is the most commonly used in a way that students are directed, guided, and taught with patience and responsibility" ${ }^{42}$.

After obtaining data on entrepreneurship education patterns, the inquiry was continued what the religious teachers used steps in guiding students to learn entrepreneurship. According to a student named Ahmad Mizari, "the steps taken by Ustadz and Ustdzah in the process of guiding us in entrepreneurship activities are through coaching or placing us into courses based on our potential, providing facilities that support our entrepreneurship activities, and providing full supports to us to be more independent and advanced, without leaving our obligation to read the Qur'an. These things are done by giving us a good education without limitation" ${ }^{43}$.

Then, Adetya Febika Sari added: "The steps taken by Ustadz and Ustadzah are: first of all, we are given an explanation concerning the intent and purpose of entrepreneurship activities at Pesantren Darussalam. After that, we are directed to courses that include two places: oyster mushroom cultivation and sewing course convection. Starting from that, we are provided with learning, guidance, and fostering about things we need to know and understand concerning entrepreneurship" ${ }^{44}$.

Information that was not less important was about the benefits of learning patterns undertaken by the Ustadz / Ustadzah for students' entrepreneurship learning. According to Ahmad Mizari, "The benefits gained from the applied educational patterns are making the students responsible, and most importantly students get many experiences from such patterns. Besides, students become

\footnotetext{
${ }^{41}$ Interview with Ustadz Heru, October 26th, 2019

${ }^{42}$ Interview with Ustadz Agus Salim, October 23rd, 2019

${ }^{43}$ Interview with a student, Ahmad Mizari, October 13th, 2019

${ }^{44}$ Interview with a student, Adetya Febika Sari, November 20th, 2019.
} 
more independent, creative, and innovative. The most impressive thing for us is that Ustadz and Ustadzah are so compassionate with infinite patience" ${ }^{45}$.

Based on the data presented above, it could be summarized that the training applied at Pesantren Darussalam of Kepahiang in developing students' entrepreneurial potential tended to be a democratic pattern (authoritative), whereby, in this case, Kiai gave authority to the teachers who took charge of coaching students in terms of entrepreneurship activities so that the teachers could guide, direct, and foster students to participate in entrepreneurial activities at the Pondok Pesantren Darussalam.

In the way as the above-mentioned, students were given an opportunity and extensive time to develop their potential in the field of entrepreneurship by involving them in courses such as convection (sewing), oyster mushroom cultivation, and Santricooperatives, where students were taught and guided to become individuals who were responsible, disciplined, creative, independent, and innovative as well as tough. The coaching processes also gave students rights and obligations in a balanced manner, and at the same time, not forgetting to keep controlling students to increase their Islamic spiritual values. In principle, it should also be noted that entrepreneurship's spirit will grow well if it is in line with entrepreneurial interests ${ }^{46}$.

Based on observations the researcher made, there were no many differences in the facts garnered from interviews with Ustadz and Ustadzah, who became the coaches of entrepreneurship activities at Pesantren Darussalam of Kepahiang.

Based on the researcher's observations, the pattern of education applied by Ustadz and Ustadzah in the framework of guiding and fostering students in entrepreneurship activities was a democracy (authoritative). It was evidenced by the treatment of Ustadz and Ustadzah's attitudes that were full of responsibility, directing or controlling students during these activities carried out with patience. Also, Ustadz and Ustadzah indeed really guided and taught the things related to entrepreneurship. It is an effort to develop students' potential as regards entrepreneurship skills ${ }^{47}$.

Based on this study's documentation, the data on how Ustadz and Ustadzah applied the educational patterns in guiding and fostering students' entrepreneurship activities was obtained. The data were obtained through photographs related to students' activities in entrepreneurship education. Such documentation data extended to the portraits of facilities, infrastructure,

${ }^{45}$ Interview with a student, Ahmad Mizari, October 29th, 2019

${ }^{46}$ Miko Polindi, "Pengaruh Karakter Entrepreneur terhadap Minat Berwirausaha (Studi Empiris pada Santri di Pondok Pesantren Al-Ittifaq Ciwidey Bandung)," Al-Intaj: Jurnal Ekonomi Dan Perbankan Syariah 5, no. 1 (2019): 63-82.

${ }^{47}$ Observation, December28th,2019. 
management structures of students' entrepreneurship activities, and overall activities students were engaged. ${ }^{48}$

\section{Supporting and Inhibiting Factors as Regards the Implementation of Entrepreneurship Activities}

\section{Supporting Factors}

Based on the data garnered using interviews, observation, and documentation, coaching students' supporting factors develop their entrepreneurship potential.

According to the Head of Pesantren Darussalam in Kepahiyang Regency o Bengkulu province, the supporting factors regarding the implementation of Entrepreneurship activities in Pesantren Darussalam went well. He said, "These entrepreneurship activities need to be maintained and given a big appreciation. These activities also deserve full supports to build independence among students in a persistently better way capably. This Pesantren is thankful for having Ustadz and Ustadzah who provide good educational patterns in guiding and directing students to participate in entrepreneurship activities" ${ }^{49}$.

It was confirmed by H. Agus Salim, who said: "It must be understood that the success of education is inseparable from good management and the consistency of what has become a joint decision. Therefore, if it is associated with entrepreneurship activities, it certainly cannot be separated from good management and seriousness having been afforded by Ustadz and Ustadzah. Through good and consistent educational patterns, good results will be generated as well. In such a way, entrepreneurship activities at Pesantren Darussalam can persistently exist and progress" ${ }^{50}$.

Next, the researcher interviewed Ahmad Mizari, one of the students from class XII who participated in entrepreneurship activities. He said, "In guiding and fostering, the mentors and coaches gave students stimulation to arise students' enthusiasm about participating in entrepreneurship activities. The stimulation provided was in the form of motivation, full attention, strong guidance, and providing optimal educational patterns" ${ }^{51}$.

That response was strengthened by the data from field observations that one of the supporting factors was providing educational patterns from the Ustadz and Ustadzah, which were very warmly felt by the students in providing direction and guidance, fostering, and training them. The educational patterns

\footnotetext{
${ }^{48}$ Documentation data obtained from activities at the Pesantren

${ }^{49}$ Interview with the Head of Pesantren Darussalam, November 18th, 2019

${ }^{50}$ Interview with a teacher, H. Agus Salim, November 22nd, 2019

${ }^{51}$ Interview with a student, Ahmad Mizari,December 10th, 2019
} 
were supported by several facilities needed to improve the quality and students' potential in entrepreneurship training ${ }^{52}$.

When observing more deeply the implementation of the learning students dealt with in entrepreneurship activities, it could be seen that the local community's environment, both the general public as well as students' parents, also provided supports for students. Both parents and the general public seemed to give some input beneficial to students by giving suggestions to the Pesantren ${ }^{53}$.

Kiai and teachers' roles and supports indeed contribute greatly to the increase in students' interest in being creative, including in developing entrepreneurial interests. Dewi Lailain her research stated that Kiai, santri (students), curriculum, and infrastructure are four important pillars supporting students to be successful when they return to society ${ }^{54}$. It is in line with Tiantian Liu et al., who said one of the factors supporting one's interest in entrepreneurship is the environment $t^{55}$. There are also research findings revealing that entrepreneurial interest is driven by entrepreneurship education created around them ${ }^{56}$. It means that if Pesantren has placed entrepreneurship education as a priority program, of course, students' interest in entrepreneurship will further develop.

\section{Inhibiting Factors}

To obtain information pertinent to the inhibiting factors of entrepreneurial educational activities at Pesantren Darussalam, the researcher conducted interviews with several informants, both religious teachers (Ustadz and Ustadzah) and students. As stated by a student named Ahmad Mizari, "The inhibiting factor is that there is no organization that houses students to gather with fellow entrepreneurs in Kepahiang regency for the sake of exchanging or developing ideas. Besides, there are inadequate mechanical workshops, sewing machines, and others" $" 57$.

The opinion above was also added by Iqbal Fathurrahman Syah, who said, "Some students are sometimes less aware of taking benefits from the supports and appreciation given by Pesantren leader. This condition can harm the students themselves. It isn't easy to build students' awareness. Perhaps it is because of

${ }^{52}$ Observation, December 17th, 2019

${ }^{53}$ Observation, December 17th, 2019

${ }^{54}$ Dewi Laila Hilyatin, "Pemberdayaan Kewirausahaan Santri Berbasis Madrasah Santripreneur Di Pondok Pesantren Darussalam," Al-Amwal: Jurnal Ekonomi Dan Perbankan Syari'ah 7, no. 2 (2016).

55 Tiantian Liu et al., "Entrepreneurship Education in China," Journal of Entrepreneurship in Emerging Economies, 2020.

${ }^{56}$ Ghulam Nabi et al., "Does Entrepreneurship Education in the First Year of Higher Education Develop Entrepreneurial Intentions? The Role of Learning and Inspiration," Studies in Higher Education 43, no. 3 (2018): 452-467.

${ }^{57}$ Interview with a student, Ahmad Mizari, December 24th, 2019. 
students' few experiences. If students' awareness has been well-developed, students' enthusiasm and sincerity will increase as well. This issue seems to hinder the application of education patterns, leading to stagnancy regarding the development of some students ${ }^{58}$.

Of course, the inhibiting factors above are very relative, and not all Pesantrens that develop entrepreneurship education have the same constraints. For example, the results of Anas's research at Pesantren Wahid Hasyim in Yogyakarta indicated that obstacles concerning entrepreneurial activities are associated with the lack of students' self-confidence in developing their entrepreneurial skills ${ }^{59}$. It is also different from Pesantren Ma'had Mambaul Hikam Jombang, having been studied by Makrifatul Ilmi that the most inhibiting factor in entrepreneurship education at that Pesantren is the lack of guidance from the government in the field of entrepreneurship ${ }^{60}$.

\section{CONCLUSION}

Kiai and Teachers' (Ustadz and Ustadzah) pattern in developing students' entrepreneurial potential indicates an authoritative type of democracy. Kiai gives authority to the council of teachers responsible for students' entrepreneurial activities to guide, direct, and foster students who participate in entrepreneurial activities. The supporting factors for the coaching of entrepreneurial activities are as follows: full supports and appreciation from Kiai for students' entrepreneurial activities, the availability of several supporting facilities for students' entrepreneurship education, and supports from the surrounding community around Pesantren Darussalam of Kepahiang. The inhibiting factors fall into the following points: no organization helps accommodate students in carrying out entrepreneurial activities and the lack of some students' awareness in terms of taking benefits from Kiai and teachers' supports

${ }^{58}$ Interview with a student, Iqbal Fathurrahman Syah, December 24th, 2019

${ }^{59}$ Ibnu Anas, "Lembaga Pengembangan Keterampilan dan Kewirausahaan (Lpk2) dalam Mengembangkan Wirausaha Santri di Pondok Pesantren Wahid Hasyim Yogyakarta,”Jurnal Elektronik Mahasiswa Pend. Luar Sekolah-S1 7, no. 7 (2018): 824-829.

${ }^{60}$ Makrifatul Ilmi, "Menumbuhkan Jiwa Entrepreneurship Santri Melalui Pengembangan Budaya Kewirausahaan Berbasis Syariah Pada Pondok Pesantren Mambaul Hikam (MMH) Jombang" (PhD Thesis, UIN Sunan Ampel Surabaya, 2016). 


\section{REFERENCES}

Ahmad, AnshoriMaulana, and YefniYefni. "KontribusiPondok Pesantren Hafizh Al-Qur'an Al-Fathdalam Pembangunan Masyarakat Di KampungBentengHuluKecamatanMempuraKabupatenSiak.”

JurnalRisetMahasiswaDakwah Dan Komunikasi 2, no. 1 (2020): 31-36.

Aloia, Lindsey Susan, and Ron Warren. "Quality Parent-Child Relationships: The Role of Parenting Style and Online Relational Maintenance Behaviors." Communication Reports 0, no. 00 (2019): 1-14. https://doi.org/10.1080/ 08934215.2019 .1582682$.

Anam, Saeful. "Pesantren Entrepreneur Dan AnalisisKurikulum Pesantren MukminMandiriWaruSidoarjoDalamPengembanganDunia Usaha." Maraji: JurnalIlmuKeislaman 2, no. 2 (2016): 304-329.

Anas, Ibnu. "LembagaPengembanganKeterampilandanKewirausahaan (Lpk2) DalamMengembangkanWirausahaSantri di Pondok Pesantren Wahid Hasyim Yogyakarta." JurnalElektronikMahasiswa Pend. Luar Sekolah-S1 7, no. 7 (2018): 824-829.

Andriyani, Zuanita, M. AzmiHasan, and RetnoAyuWulandari. "MembangunJiwaEnterpreneurshipSantriMelaluiPengembangan Usaha EkonomiKreatif." Dimas: JurnalPemikiran Agama UntukPemberdayaan 18, no. 1 (2018): 47-64.

Asmani, Jamal Ma'mur. "Pesantren Sebagai 'Kiblat' PendidikandanPengetahuan Indonesia." Islamic Review: JurnalRiset Dan KajianKeislaman 5, no. 1 (2016): 59-84.

Barton, Alison L., and Jameson K. Hirsch. "Permissive Parenting and Mental Health in College Students: Mediating Effects of Academic Entitlement." Journal of American College Health 64, no. 1 (2016): 1-8. https://doi.org/ 10.1080/07448481.2015.1060597.

Colorafi, Karen Jiggins, and Bronwynne Evans. "Qualitative Descriptive Methods in Health Science Research." HERD: Health Environments Research \& Design Journal 9, no. 4 (2016): 16-25.

Djumransjah, H. M. "Pendidikan Pesantren Dan KemandirianSantri." JurnalllmuPendidikan 8, no. 2 (2016). 
Fauzi, Yusni. "Peran Pesantren Dalam Upaya Pengembangan Manajemen Sumber Daya Manusia (Msdm) Entrepreneurship (PenelitianKualitatif

Di Pondok Pesantren Al-IttifaqRancabali Bandung)." JurnalPendidikan UNIGA 6, no. 1 (2017): 1-8.

Georgiou, Stelios N., Panayiotis Stavrinides, and Kyriaki Fousiani. "Authoritarian

Parenting, Power Distance, and Bullying Propensity.” International Journal of School and Educational Psychology 1, no. 3 (2013): 199-206. https:// doi.org/10.1080/21683603.2013.806234.

Ghofur, Abdul. "SongkokCelleng." Dakwatuna: JurnalDakwah Dan Komunikasi Islam 6, no. 01 (2020): 35-55.

GironésGuillem, Purificación, Dolores Burguete, Regimar Machado, Juan Mario DomínguezSantamaría, and Manuel Lillo-Crespo. "Qualitative Research Process Applied to Organ Donation,” 2018.

Hadi, Sumasno. "PemeriksaanKeabsahan Data PenelitianKualitatifPadaSkripsi." JurnallmuPendidikan 22, no. 1 (2017).

Hills, Gerald E., and Michael H. Morris. "Entrepreneurship Education: A Conceptual Model and Review." In Educating Entrepreneurs for Wealth Creation, 38-53. Routledge, 2018.

Hilyatin, DewiLaila. "PemberdayaanKewirausahaanSantriBerbasis Madrasah Santripreneur Di Pondok Pesantren Darussalam.” Al-Amwal:JurnalEkonomi Dan PerbankanSyari'ah 7, no. 2 (2016).

Ilmi, Makrifatul. "MenumbuhkanJiwa Entrepreneurship Santri Melalui Pengembangan Budaya Kewirausahaan Berbasis Syariah Pada Pondok Pesantren Mambaul Hikam (MMH) Jombang." PhD Thesis, UIN SunanAmpel Surabaya, 2016.

Khoiruddin, Muhammad, 'Integrasi Kurikulum Pesantren Dan Perguruan Tinggi', Cendekia, 17.2 (2019), 219-34

Kholis, Nur. "Pondok Pesantren SalafSebagai Model PendidikanDeradikalisasiTerorisme.” Akademika: JurnalPemikiran Islam 22, no. 1 (2017): 153-172.

King, Keith A., Rebecca A. Vidourek, and Ashley L. Merianos. "Authoritarian Parenting and Youth Depression: Results from a National Study." Journal of Prevention and Intervention in the Community 44, no. 2 (2016): 13039. https://doi.org/10.1080/10852352.2016.1132870. 
Lau, Eva Yi Hung, and Thomas G. Power. "Coparenting, Parenting Stress, and Authoritative Parenting among Hong Kong Chinese Mothers and Fathers." Parenting, 2019, 1-10. https://doi.org/10.1080/15295192.2019.1694831.

Liu, Tiantian, Keith Walley, Geoff Pugh, and Paul Adkins. "Entrepreneurship Education in China." Journal of Entrepreneurship in Emerging Economies, 2020.

Martono, Nanang. MetodePenelitianKuantitatif: Analisis Isi Dan Analisis Data Sekunder (SampelHalaman Gratis). RajaGrafindoPersada, 2010.

Mawardi, Sumari. "PolaPendidikanKyai Abdul Malik LuqoniPengasuhPondok Pesantren MinhajutThullabSumberberasMuncarBanyuwangi." Jurnal Darussalam: JurnalPendidikan, Komunikasi Dan PemikiranHukum Islam 8, no. 1 (2016): 95-114.

Mcmullan, W. Ed, and Wayne A. Long. "Entrepreneurship Education in the Nineties." Journal of Business Venturing 2, no. 3 (1987): 261-275.

Miles, Matthew B., A. Michael Huberman, and Johnny Saldaña. Qualitative Data Analysis: A Methods Sourcebook. 3rd. Thousand Oaks, CA: Sage, 2014.

Moleong, Lexi J. Methodology of Qualitative Research. Bandung: RemajaRosdaKarya, 2010.

Mubarok, Achmat. "Pendidikan Entrepreneurship dalamMeningkatkanKemandirianSantriPondok Pesantren Al-Hidayah Ii SukorejoPasuruan." Al Murabbi 4, no. 1 (2018): 1-22.

Mukaffan, and Ali Hasan Siswanto, 'Modernisasi Pesantren Dalam Konstruksi Nurcholish Madjid', Cendekia, 17.2 (2019), 285-300

Nabi, Ghulam, Andreas Walmsley, Francisco Liñán, Imran Akhtar, and Charles Neame. "Does Entrepreneurship Education in the First Year of Higher Education Develop Entrepreneurial Intentions? The Role of Learning and Inspiration." Studies in Higher Education 43, no. 3 (2018): 452-467.

Natsir, Ahmad, 'Identitas Poskolonialisme Pesantren Modern', Cendekia, 17.2 (2019), 203-18

Noviyanti, Ririn. "PeranEkonomiKreatifTerhadapPengembanganJiwa Entrepreneurship Di Lingkungan Pesantren." INTAJ: JurnalPenelitianIlmiah 1, no. 1 (2017): 77-99. 
Polindi, Miko. "PengaruhKarakter Entrepreneur terhadapMinatBerwirausaha (StudiEmpirisPadaSantri Di Pondok Pesantren Al-IttifaqCiwidey Bandung).” Al-Intaj: JurnalEkonomi Dan PerbankanSyariah 5, no. 1 (2019): 63-82.

Rahayu, Titi. "MenumbuhkanJiwa Dan Kompetensi Kewirausahaan Berbasis Syariah Bagi Mahasiswa Fakultas Ekonomi Dan Bisnis Islam Institut Agama Islam Bakti Negara (Ibn) Tegal.” Iqtishodiah: JurnalEkonomi Dan PerbankanSyariah 1, no. 1 (2019): 73-88.

Ren, Huiguang, Charissa S L Cheah, Biao Sang, and Junsheng Liu. "Maternal Attribution and Chinese Immigrant Children's Social Skills: The Mediating Role of Authoritative Parenting Practices." Parenting Science and Practice, 2019, 1-11. https://doi.org/10.1080/15295192.2019.1694834.

Riswanto, Ari. "PendampinganKreativitas Dan Kemandirian: PendidikanCalonWirausahawanMuda.” Edusentris 3, no. 3 (2016): 300305.

Rochayati, Umi, MahardhikaSetiaKusumawardani, and Arum Kartika Sari. "PENGARUH FAKTOR SOSIODEMOGRAFI, SIKAP, DAN KONTEKSTUAL TERHADAP NIAT BERWIRAUSAHA SISWA.” JurnalKependidikan: PenelitianInovasiPembelajaran 43, no. 2 (November 1, 2013). https://doi.org/10.21831/jk.v43i2.1970.

Roulston, Kathryn. "Analysing Interviews.” The Sage Handbook of Qualitative Data Analysis, 2014, 297-312.

Rukajat, Ajat. PendekatanPenelitianKualitatif (Qualitative Research Approach). Deepublish, 2018.

Rumawouw, GertruidaJohona. "Praktek Wirausaha Bagi Mahasiswa Dalam Meningkatkan Ekonomi." Prosiding Aptekindo 6, no. 1 (2012).

Setiawan, AlbiAnggito, Johan. Metodologipenelitiankualitatif. CV Jejak (Jejak Publisher), 2018.

Setiawan, HeriCahyoBagus. "KontribusiPraktikKewirausahaan Di Pondok Pesantren (StudiPadaPondok Pesantren Entrepreneur MukminMandiri, WaruSidoarjo).” JurnalRiset Entrepreneurship 2, no. 2 (2019): 8-18.

Shumow, Lee, Deborah Lowe VandellL, and Jill K. Posner. "Harsh, Firm, and Permissive Parenting in Low-Income Families.” Journal of Family Issues 19, no. 5 (1998): 483-507. https://doi.org/10.1177/019251398019005001. 
Siswanto, Siswanto. "The Exploration of Pesantren-Based Entrepreneurship Development Strategy through TelEology Approach.” El Harakah 20, no. 2 (2018): 191.

Sukanti, Sukanti, AliyahRasyidBaswedan, and IsroahIsroah. "PeranIbuDalamMenumbuhkanJiwaWirausahaAnak." JurnalPendidikanAkuntansi Indonesia 9, no. 2 (2011).

Sulandjari, Rekno.

"StrategiKomunikasiPemasaranPadaMinatBerwirausahaProdukLokal (KerajinanBambu) Di KWD KelurahanPulutanKecamatanSidorejo Kota Salatiga.” JurnalEgaliter 2, no. 03 (2018).

Supriadi, Dedi. "PokoknyaKualitatif: Dasar-DasarMerancang Dan MelakukanPenelitianKualitatif.” Jakarta: PT. DuniaPustaka Jaya, 2011.

Surur, AgusMiftakus. "PeningkatanKemampuanKhatabah (Public Speaking Skill) SantriMa'hadDarulHikmah Iain Kediri." IjazArabi Journal of Arabic Learning 1, no. 2 (2018).

Suwendra, I. Wayan. MetodologiPenelitianKualitatifDalamIlmuSosial, Pendidikan, Kebudayaan Dan Keagamaan. Nilacakra, 2018.

Syafe'i, Imam. "Pondok Pesantren: LembagaPendidikanPembentukanKarakter." Al-Tadzkiyyah: JurnalPendidikan Islam 8, no. 1 (2017): 61-82.

Uji, Masayo, Ayuko Sakamoto, Keiichiro Adachi, and Toshinori Kitamura. "The Impact of Authoritative, Authoritarian, and Permissive Parenting Styles on Children's Later Mental Health in Japan: Focusing on Parent and Child Gender." Journal of Child and Family Studies 23, no. 2 (2014): 293-302. https://doi.org/10.1007/s10826-013-9740-3.

Warsah, Idi, 'Pendidikan Keimanan Sebagai Basis Kecerdasan Sosial Peserta Didik: Telaah Psikologi Islami', Psikis: Jurnal Psikologi Islami, 4.1 (2018), $1-16$

Warsah, Idi, and Muhamad Uyun, 'Kepribadian Pendidik: Telaah Psikologi Islami', Psikis : Jurnal Psikologi Islami, 5.1 (2019), 62-73 <https://doi. org/10.19109/psikis.v5i1.3157>

Warsah, Idi, and NuzuarNuzuar. "AnalisisInovasiAdministrasi Guru DalamMeningkatkanMutuPembelajaran (Studi Man RejangLebong).” Edukasi 16, no. 3 (2018): 294572. 
230 Idi Warsah, Entrepreneurship Education in Pesantren

Wiranata, Rz Ricky Satria. "Tantangan, Prospek Dan Peran Pesantren DalamPendidikanKarakter Di Era RevolusiIndustri 4.0.” Journal Al-Manar 8, no. 1 (2019): 61-92.

Zuhriy, M.Syaifuddien. "Budaya Pesantren Dan PendidikanKarakterPadaPondok Pesantren Salaf." Walisongo: JurnalPenelitianSosialKeagamaan 19, no. 2 (2011): 287-310. 